\title{
Situation of Intimate Partner Violence among University Female Students in Nepal: Findings of a Cross-Sectional Survey
}

Bhagabati Sedain

\section{Abstract}

Intimate partner violence (IPV) is one of the most common forms of violence in our society. Intimate partner violence among Nepali female university students, in particular, has not yet been studied. Therefore, across-sectional survey was conducted among female students studying in bachelors and masters level at Padmakanya Campus using structured and semi-structured questionnaires. A total of 370 participants were randomly selected and data were collected from the 1 December 2013 to 30 January 2014. One-thirds of the respondents were married. Married participants reported about their violence experience perpetrated by their husbands. The prevalence of emotional violence $40 \%$ was higher than physical $33 \%$ and sexual violence $20 \%$. Women with landownership, employed, members of community groups and those who were married to husbands with the higher level of education were less likely to experience physical violence. Women who did not own land $(\mathrm{OR}=2.92)$, unemployed $(\mathrm{OR}=1.21)$ were more likely to experience violence than those who owned land and were employed. Similarly, lower level of husband's education $(\mathrm{OR}=3.35)$ and unskilled jobs $(\mathrm{OR}=1.56)$ were associated with the higher occurrence of violence compared to their husbands having university level of education and government job or working abroad. Prevalence of IPV is common among educated girls. 
Efforts to reduce IPV should give priority for educated women in Nepal.

Keywords - Emotional violence, Intimate Partner Violence, physical violence, sexual violence, survey, university female students

\section{Introduction}

Highly educated Nepalese girl's and women's experience of Intimate Partner Violence (IPV) is lacking. There are some studies on experience of IPV, which have been undertaken in the recent years (Asia Foundation, 2010; Adhikari, \&Tamang, 2010; Government of Nepal, 2012 \& Puri et al., 2015). However, these studies presented data on the violence experience of rural, poor uneducated female respondents. This gap of information has created difficulties in getting the real picture of the IPV among educated girls and women in Nepal. The study by Hawkes et al. (2013) quoted that lack of education is the cause of IPV in Nepal.

Women and girls experience gender-based violence throughout their life from a fetus, infancy, childhood through adolescence, and adulthood to old age. Intimate Partner Violence is one of the most challenging and common forms of violence against women perpetrated by a husband or other intimate partner (Watts \& Zimmerman, 2002). IPV severely impacts many girls and women in various forms including physical, psychological and sexual regardless of age, religion, ethnicity, culture, economic status, and geography and severely impacts many girls and women; yet this issue is 
significantly under-reported (Palermo, Peterman \& Peterman, 2014).

World Health Organization has defined IPV as "behaviour within an intimate relationship that causes physical, sexual or psychological harm, including acts of physical aggression, sexual coercion, and psychological abuse and controlling behaviours" (Butchart, Garcia-Moreno\&Mikton, 2010). The physical violence ranging from slaps punches and kicks to assaults with a weapon and homicide and sexual violence includes forced sex and other forms of sexual coercion (WHO, 2012). The psychological violence has taken in different forms such as prohibiting a woman from seeing her family and friends, ongoing belittlement or humiliation, or intimidation; economic restrictions such as preventing a woman from working, or confiscating her earnings; and other controlling behaviours by an intimate partner (WHO, 2012). Multiple risk factors including early marriage, low level of education, low level of economic status, history of abuse during childhood, alcohol use, drug abuse, unequal power relations and conflicting marital relationship have been found to be associated with the IPV (Speizer\& Pearson, 2012; Gass,Stein, William\&Seedat, 20011). IPV has a severe negative impact short and long-term physical, mental, sexual health problems and social well-being of the victims as well as their family, with an adverse effect on parenting skills and on educational and employment outcomes (Staggs \&Riger, 2005). Regarding its detrimental consequences on women's health, social life and economic welfare IPV is recognized as a global problem (WHO, 2005). 
IPV is the most common hidden form of violence against women (Palermo, Peterman \& Peterman, 2014). Prevalence of IPV varies by age; studies shows that adolescence and early adult married or cohabiting women are at high risk of intimate partner violence (Garcia-Moreno, Jansen, Ellsberg, Heise, Watts, 2006; Decker, et al.2014; Stöckl, March, Pallitto, \& Garcia-Moreno, 2014). WHO's Multi-Country Study on women's Health and Domestic Violence against Women presented that globally 15-71\%of women experience intimate partner violence at some point in their lives (Garcia-Moreno, Jansen, Ellsberg, Heise, \& Watts, 2006). The variation depends on factors such as cultural norm, social settings and laws that are favorable/unfavorable to gender inequity.

Intimate partner violence, particularly by a husband is one of the major violence in South Asia. Research findings indicated that poverty, low level of education, unemployment, alcohol consumption, witnessing violence in childhood, acceptance of violence, quarrelling between partners, work stress were the key factors associated with perpetrations of intimate partner violence (Jewkes,2002; Adhikari \& Tamang, 2010; Fulu, et al.2013; Ellsberg, et al.2015).

World Health Organization's global and regional estimate of IPV showed that $30 \%$ of all women who have been in a relationship have experienced physical and sexual violence by their intimate partner. According to Fulu, (2013), the lifetime prevalence of IPV among ever-partnered women was ranged from $25 \% \mathrm{t}$ to $68 \%$ in Asia-Pacific region. Similarly analysis of the South Asian countries' Demographic Health Surveys data revealed that $43 \%$ of women experienced intimate partner violence (Solotaroff \& Pandey, 2014). Although information 
on the IPV in the developing countries is limited, literature shows that Nepal is $11^{\text {th }}$ among the 15 countries with the highest prevalence of physical intimate partner violence in the world (Solotaroff \& Pandey, 2014). The Nepal Demographic and Health Survey (NDHS) 2011also found that one-third of Nepalese females suffered any form of violence 12 months preceding the survey. The data also revealed that about $28 \%$ of ever-married women experienced sexual and physical violence from their husband (Tuladhar, Khanal, Ghimire, \& Onta, 2013).

Most of the violence against women cases remains unreported, and the cases are settled without legal intervention due to social pressure on victims (Asia Foundation, 2010). Despite these challenges, some of the empirical evidence on violence against women presented that about $50 \%$ of Nepalese women experienced violence at some point of time; $75 \%$ of them were from intimate partners and $60 \%$ of the victims never expressed their experiences to others (Government of Nepal, 2012). Likewise, another study on the prevalence and determinant of sexual violence against young married women by husband revealed that $46 \%$ of young married women experienced sexual violence by their husband in their life, and $31 \%$ experienced sexual abuse within the last 12 months of the study (Puri, Frost, Tamang, Lamichhane, \&Shah, 2012).

Importance of research on IPV has been getting attention in Nepal. It is believed that the problem is prevalent largely among rural, poor and uneducated females. However, the level of education was not found to be significant determinant of intimate partner violence and violence transcend both 
educated and uneducated women (Puri, Frost, Tamang, Lamichhane,\& Shah, 2012).Therefore, this paper aims to provide evidence based information on the prevalence of IPV among university level female students in Nepal.

\section{Methods}

Study area

Thecross-sectional study was carried out in among the sample students studying at Bachelor's and Master's level at Padmakanya Multiple Campus. About 3,000 female students from different parts of the country with different socioeconomic status in Bachelor's and Master's level in 2013/14 academic year. Considering the higherrepresentation of the educated Nepalese female population Padmakanya Multiple campus was selected.

\section{Sample}

The sample population was selected irrespective of the age, ethnic group, and religion, place of residence, socio-economic status and marital status. The study sample size was estimated by using the government's estimation of violence against women $48 \%$ (Government of Nepal, 2012)as a proportion at $95 \%$ confidence interval, $5 \%$ margin of error and $30 \%$ nonresponse rate. A final sample size was 500 female students. 


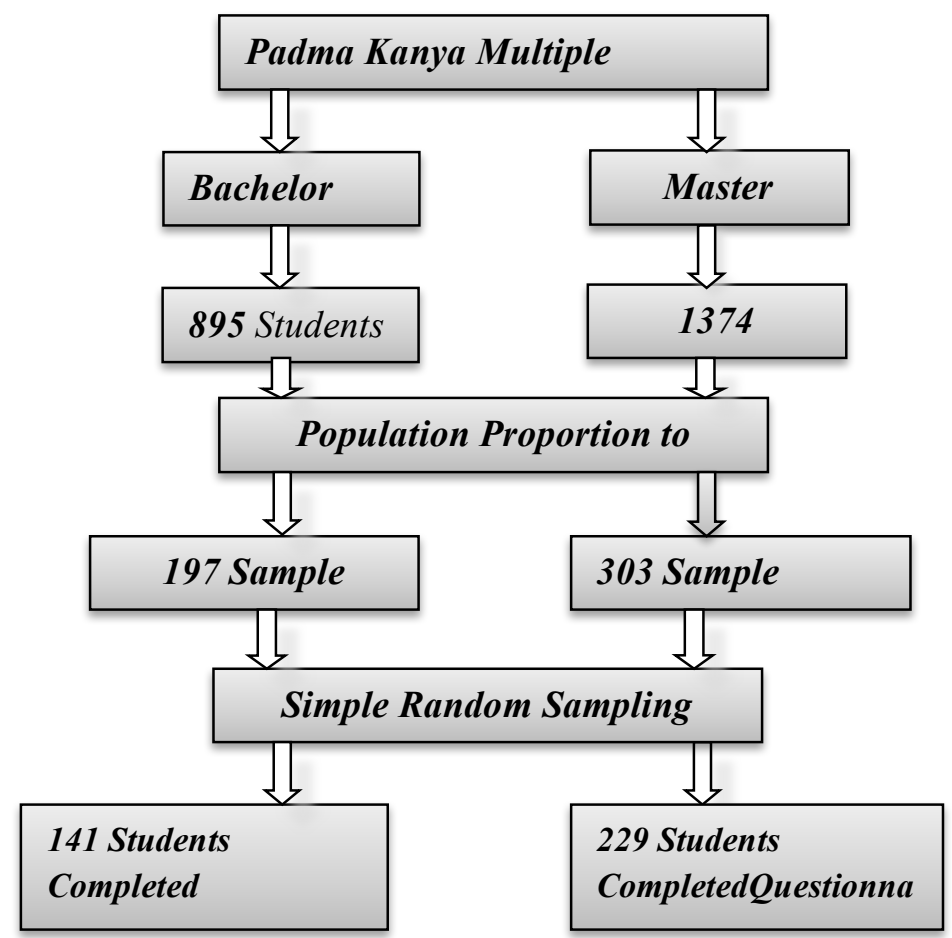

Figure 1. Sampling technique and study flowchart

A detailed list of names, address, place of residence and phone number of all 2,269 students enrolled in Bachelor's and Master's levelwas accessed from the campus administration. The sample students were randomly selected by using random selection method for Bachelor's and Master's level separately. Population proportional to sample size was used 
to select the respondents from Bachelor's and the Master's level (Figure 1).

Selected students were personally contacted in their respective classrooms, hostel and through telephone calls. Students who were not available in the first contact were contacted again for the questionnaire. Due to irregular attendance, it was hard to get the completed questionnaire from all sample students. About $26 \%$ questionnaires were not returned; only 370 out of selected 500 female students returned the completed questionnaire.

\section{Data collection tools}

Over the course of questionnaire development various international and national surveys questionnaires on IPV was taken as reference (WHO, 2005; Ministry of Health, 2011). This study further included some questions relevant to the context. The survey questionnaire was tested among 10 female students studying at a different Campus in Kathmandu. Questionnaire was finalised by incorporating the feedbacks from pilot testing of the tools, opinions of survey experts and the mentor. The finalised English version of the questionnaire was translated into the Nepali Language. The final version of the questionnaire comprised of 7 sections with structured and semi-structured questions. The questionnaire had clear instructions and informed consent script for the participants. A self-administered questionnaire was used to collect the information. 
Data analysis

Descriptive statistics was used to describe the background characteristics of respondents and their partner. Logistic regression technique was used to identify the factors associated with the likelihood of experiencing physical and emotional violence. Place of residence, land ownership, employment, member of community groups, husband's education and types of work were taken as independent variables. Land ownership, employment was dichotomized for analysis and the place of residence was taken as rural and urban. Husband's education was grouped into four categories; primary, secondary higher education and others. Similarly, the types of works that husband involved were, not employed, labour/farming, government, business and other.

Emotional and physical violence were analyzed as dependent variable. The physical violence was measured by six items and emotional violence by five items. The respondents exposed to such violent behaviour within past 12 months or earlier were listed. The respective reference categories composed of the participants with urban residence, having own land, employed, husband's primary schooling and husband's type of the work.

Different independent variables and violence exposure (\%) and frequency of acts were used to indicate the prevalence of various forms of violence. To explore explanatory risk factors, intimate partner violence (experienced intimate partner violence or did not experience intimate partner violence) was modeled with binary logistic regression as a function of each independent variables. The risk factors were 
estimated with their $95 \%$ confidence interval by binary logistic regression analysis.

Research ethics

Ethical approval was obtained from Tribhuvan University, Office of The Rector, Research Division at Kirtipur and from the Padma Kanya Campus Administration. Moreover, the participants were requested to give their written consent to participate in the survey.

\section{Results}

Socio-demographic characteristics of the respondents

The majority of the sample students $(62 \%)$ were from rural areas of Nepal, over half (53\%) of them were living in a rented room in Kathmandu, 21\% lived in their home, and 33\% were married. About $11 \%$ of them had solely/jointly land ownership in their original address, and 36\% were currently employed - partially or fully (Those students studying in the morning shifts can have time to work for full time). About three-fourth of the employed participants mentioned that their salaries were insufficient to cover their expenses; therefore, they depended on their family members for financial support. Only $38 \%$ were involved with community group/organisations (e.g. civic/ political union, social work/ charitable organisations, economic/ micro finance, women's organisation, religious organisations, sports/arts/ crafts), 
where $12 \%$ reported that they were prevented from participating in any community group activities (Table 1).

Table 1. Distribution of university female students by their background characteristics

\begin{tabular}{|l|c|c|}
\hline \multicolumn{1}{|c|}{$\begin{array}{c}\text { Respondents } \\
\text { Characteristics }\end{array}$} & Frequency & Percent \\
\hline Education & 141 & 38.1 \\
\hline Bachelor & 229 & 61.9 \\
\hline Master & & \\
\hline Place of Residence & 241 & 65.1 \\
\hline Rural & 129 & 34.9 \\
\hline Urban & & \\
\hline Marital Status & 247 & 66.7 \\
\hline Unmarried & 123 & 33.2 \\
\hline Married & & \\
\hline $\begin{array}{l}\text { Sole or jointly Land } \\
\text { Ownership }\end{array}$ & 40 & 10.8 \\
\hline Yes & 330 & 89.2 \\
\hline No & & \\
\hline $\begin{array}{l}\text { Employment (Including } \\
\text { part-time or full time) }\end{array}$ & 133 & 35.9 \\
\hline Yes & 237 & 64.1 \\
\hline No & & \\
\hline Source of Income* & 279 & 75.4 \\
\hline Family members & 135 & 36.6 \\
\hline Self-employment & 10 & 2.7 \\
\hline Agriculture/house rent & 24 & 6.5 \\
\hline Scholarship & & \\
\hline Living Arrangement & 196 & 53.0 \\
\hline Rented room & & \\
\hline & & \\
\hline
\end{tabular}




\begin{tabular}{|l|c|c|}
\hline Friend's or relative's house & 39 & 10.5 \\
\hline Hostel & 56 & 15.1 \\
\hline Home & 79 & 21.4 \\
\hline $\begin{array}{l}\text { Member of Community } \\
\text { Groups** }\end{array}$ & 141 & 38.1 \\
\hline Yes & 229 & 61.9 \\
\hline No & & \\
\hline $\begin{array}{l}\text { Prevention in } \\
\text { Participation in the } \\
\text { Community Groups }\end{array}$ & 17 & 12.1 \\
\hline Yes & 124 & 87.9 \\
\hline No & & \\
\hline
\end{tabular}

Source: Field Survey

Respondent's husband's characteristics

Overall characteristics of the married respondent's husbands are presented in Table 2. Fifty-Nine \%of the respondent's husbands were of the age between 25 and 34 years. A smaller proportion of them were in the younger (20-24) and the older (45-49) age groups $6.5 \%$ and $8 \%$ respectively. A majority (71.5\%) respondent's husbands completed higher (university) education. More than one-third (37\%) of the respondent's husbands were government employee/ foreign workers, and about one-fifth (19\%) of them were involved in daily labour/ farming. Similarly, 4\% were not involved in any income generating activities.

About 4\% of the respondent's husband consumed alcohol daily, and one-quarter of the respondents reported that their 
husbands consumed alcohol once a month. The majority of the respondents reported that their husbands (57\%) were nonalcoholic. Similarly, about one-fourth (24\%) respondents suspected that their husbands may have an extra-marital relation, and 5\% were sure about their husband's extra-marital relations. Among these married respondents, one-fifth reported that sometime they quarreled with their husbands.

Table 2. Distribution of the respondent's husbands by their background characteristics

\begin{tabular}{|l|c|c|}
\hline Husband's Characteristics & Frequency & Percent \\
\hline Age & & \\
\hline $20-24$ & 8 & 6.5 \\
\hline $25-29$ & 37 & 30.1 \\
\hline $30-34$ & 36 & 29.3 \\
\hline $35-39$ & 20 & 16.3 \\
\hline $40-44$ & 12 & 9.8 \\
\hline $45-49$ & 10 & 8.1 \\
\hline Education & & \\
\hline Primary & 17 & 13.8 \\
\hline Secondary & 12 & 9.8 \\
\hline Higher education & 88 & 71.5 \\
\hline Others & 6 & 4.9 \\
\hline Types of Work & & \\
\hline Not employed & 5 & 4.1 \\
\hline Labour/farming & 23 & 18.7 \\
\hline Government/Foreign worker & 45 & 36.6 \\
\hline Business & 30 & 24.4 \\
\hline Other & 20 & 16.3 \\
\hline Drinking Habit of husband & & \\
\hline Daily & 5 & 4.1 \\
\hline
\end{tabular}




\begin{tabular}{|l|c|c|}
\hline 1-2 Times in a week & 16 & 13.0 \\
\hline Once in a month & 30 & 24.4 \\
\hline Never & 70 & 56.9 \\
\hline Don't know & 2 & 1.6 \\
\hline Extra- marital Relation & & 4.9 \\
\hline Yes & 6 & 65.9 \\
\hline No & 81 & 29.3 \\
\hline May be & 36 & \\
\hline $\begin{array}{l}\text { Frequency of Quarrelling } \\
\text { between Respondents and } \\
\text { their Husband }\end{array}$ & 98 & 79.7 \\
\hline Never & 25 & 20.3 \\
\hline Sometime or often & & \\
\hline
\end{tabular}

Source: Field Survey

\section{Prevalence of violence}

Table 3elucidates proportion of the respondents victimised by their husbands at any point of their life and within 12 months before the interview. Respondents mentioned that commonly occurring forms of emotional violence were being insulted or made feel bad (31\%), did things to scare or intimidate on purpose $(7 \%)$ and belittled or humiliated in front of other people $(1.6 \%)$. Being slapped or thrown something, pushed or shoved or pulled, hit or with something else that hurt and kicked or dragged or beaten; $22.0 \%, 3.3 \%, 7.3 \%$ and $0.8 \%$ respectively were some common forms of physical violence. Regarding two forms of sexual violence usually occurring were forced to have sexual intercourse without consent to (20.3\%) and followed by had sexual intercourse when did not 
want to because they were afraid of what their partner might do if they refused (11.4\%).

Table 3. Experience of intimate partner violence (IPV) by the married female university students

\begin{tabular}{|l|c|c|}
\hline Types of Violence* & Frequency & Percent \\
\hline Emotional Violence & $\mathbf{4 9}$ & $\mathbf{3 9 . 8}$ \\
\hline Insulted you made you feel bad & 38 & 30.9 \\
\hline $\begin{array}{l}\text { Belittled or humiliated you in front of } \\
\text { other people }\end{array}$ & 2 & 1.6 \\
\hline $\begin{array}{l}\text { Did things to scare or intimidate you on } \\
\text { purpose }\end{array}$ & 9 & 7.3 \\
\hline Never commit emotional violence & 74 & 60.2 \\
\hline $\begin{array}{l}\text { Any type of emotional violence in the } \\
\text { past 12 months }\end{array}$ & 41 & 33.3 \\
\hline Physical Violence & $\mathbf{4 1}$ & $\mathbf{3 3 . 3}$ \\
\hline Ever slapped or thrown something & 27 & 22.0 \\
\hline Ever pushed or shoved or pulled hair & 4 & 3.3 \\
\hline Ever hit or with something else that hurt & 9 & 7.3 \\
\hline Ever kicked or dragged or beaten & 82 & 66.7 \\
\hline Never commit physical violence & 32 & 26.0 \\
\hline $\begin{array}{l}\text { Any type of physical violence in the past } \\
\text { 12 months }\end{array}$ & $\mathbf{2 5}$ & $\mathbf{2 0 . 3}$ \\
\hline Sexual Violence & 25 & 20.3 \\
\hline $\begin{array}{l}\text { Ever been forced to have sexual } \\
\text { intercourse when did not want to }\end{array}$ & 14 & 11.4 \\
\hline $\begin{array}{l}\text { Ever been had sexual intercourse when } \\
\text { did not want to because you were } \\
\text { afraid of what he might do if refused }\end{array}$ & & \\
\hline
\end{tabular}

Source: Field Survey 
Factors associated with violence

Binary logistic regression was used to study the association between independent background variables with emotional and physical violence experience of the participants. Table 4 shows that land ownership and husband's higher level of education were significantly associated with the experiencing low level of emotional and physical violence. Respondents who did not have land ownership ( $\mathrm{OR}=1.46,95 \% \mathrm{CI}=0.63$ $3.38)$, and not employed $(\mathrm{OR}=1.74,95 \% \mathrm{CI}=0.95-3.17)$ were more likely to experience emotional violence. On the other hand, married respondents who were member of community organizations $(\mathrm{OR}=0.83,95 \% \mathrm{CI}=0.46-1.51)$, whose husband had higher education $(\mathrm{OR}=0.38,95 \% \mathrm{CI}=$ 0.14-0.99), government/ foreign employed $(\mathrm{OR}=0.47$, $95 \% \mathrm{CI}=0.19-1.12)$ were less likely to experience emotional violence.

Similarly, Table 4 . shows that rural $(\mathrm{OR}=1.55,9 \% \mathrm{CI}=0.83$ $2.89)$, married respondents who do not have own land $(\mathrm{OR}=$ $2.92, \mathrm{CI}=1.24-6.85)$, not employed $(\mathrm{OR}=1.21, \mathrm{CI}=0.65$ 2.27) were more likely to experience physical than urban, women with own land and employed respondents. Respondents whose husband have secondary level education experienced the higher level of physical violence $(\mathrm{OR}=3.35$, $\mathrm{CI}=1.02-10.96)$ compared to other background variables. Moreover, respondents whose husband worked as a labour worker or involve in agriculture were more likely to experience physical violence by their husband compared to those respondents whose husband were government/foreign employed. 
Table 4. Binary logistic regression analyses for the factor associated with ever experienced emotional and physical violence by a husband.

\begin{tabular}{|c|c|c|c|c|c|c|}
\hline \multirow[t]{2}{*}{ Variable } & \multicolumn{3}{|c|}{ Emotional Violence } & \multicolumn{3}{|c|}{ Physical Violence } \\
\hline & OR & $95 \% \mathrm{CI}$ & $\mathrm{P}$ & $\overline{\mathrm{OR}}$ & $95 \% \mathrm{CI}$ & $P$ \\
\hline \multicolumn{7}{|l|}{ Place of Residence } \\
\hline Urban & Reference & & & & & \\
\hline Rural & 0.99 & $\begin{array}{l}0.54- \\
1.76 \\
\end{array}$ & .940 & 1.55 & $\begin{array}{l}0.83- \\
2.89\end{array}$ & 0.170 \\
\hline \multicolumn{7}{|l|}{ Land Ownership } \\
\hline Yes & Reference & & & & & \\
\hline No & 1.46 & $\begin{array}{l}0.63- \\
3.38 \\
\end{array}$ & .375 & 2.92 & $\begin{array}{l}1.24- \\
6.85 \\
\end{array}$ & 0.014 \\
\hline \multicolumn{7}{|l|}{ Employment } \\
\hline Yes & Reference & & & & & \\
\hline No & 1.74 & $\begin{array}{l}0.95- \\
3.17\end{array}$ & .072 & 1.21 & $\begin{array}{l}0.65- \\
2.27\end{array}$ & 0.544 \\
\hline \multicolumn{7}{|l|}{$\begin{array}{l}\text { Member of } \\
\text { Community Groups }\end{array}$} \\
\hline No & Reference & & & & & \\
\hline Yes & 0.83 & $\begin{array}{l}0.46- \\
1.51\end{array}$ & .548 & 0.94 & $\begin{array}{l}0.51- \\
1.75\end{array}$ & 0.851 \\
\hline \multicolumn{7}{|l|}{ Husband's Education } \\
\hline Primary school & Reference & & & & & \\
\hline Secondary school & 1.84 & $\begin{array}{l}0.57- \\
5.92 \\
\end{array}$ & .307 & 3.35 & $\begin{array}{l}1.02- \\
10.96 \\
\end{array}$ & 0.045 \\
\hline Higher education & 0.38 & $\begin{array}{l}0.14- \\
0.99\end{array}$ & .049 & 0.65 & $\begin{array}{l}0.24- \\
1.78\end{array}$ & 0.400 \\
\hline Others & 0.62 & $\begin{array}{l}0.11- \\
3.59\end{array}$ & .594 & 0.25 & $\begin{array}{l}0.02- \\
2.62\end{array}$ & 0.250 \\
\hline \multicolumn{7}{|l|}{ Types of Work } \\
\hline Not employed & Reference & & & & & \\
\hline Labour/farming & 0.74 & $\begin{array}{c}0.08- \\
6.49\end{array}$ & .782 & 0.56 & $\begin{array}{l}0.06- \\
4.65\end{array}$ & 0.591 \\
\hline $\begin{array}{l}\text { Government/Foreign } \\
\text { worker }\end{array}$ & 0.57 & $\begin{array}{l}0.06- \\
4.81 \\
\end{array}$ & .609 & 0.33 & $\begin{array}{l}0.40- \\
2.63 \\
\end{array}$ & 0.291 \\
\hline Business & 0.43 & $\begin{array}{l}0.05- \\
3.65 \\
\end{array}$ & .438 & 0.37 & $\begin{array}{l}0.04- \\
2.96 \\
\end{array}$ & 0.346 \\
\hline Other & 1.04 & $\begin{array}{l}0.11- \\
9.65\end{array}$ & .973 & 0.72 & $\begin{array}{l}0.81- \\
6.32 \\
\end{array}$ & 0.763 \\
\hline
\end{tabular}

Source: Field Survey 


\section{Discussion}

This study found that experience of IPV among women who were more educated than their husband; particularly higher educated women having the husband with secondary school level education was higher. A similar level of husband's and wife's education has protective effects on IPV. The experience of violence among female university students was similar to the violence against young married rural women by their husband in Nepal (Lamichhene, Puri, Tamang, \&Dulal,2011). This study concludes that about one-third of university level female students have experienced violence by their intimate partner in Nepal. The data shows that educated women were open to discuss GBV issues. IPV was the prevalent problem in Nepal and educated women had also experienced all forms of violence in their life time as well as within past 12 months of the interview by their husband.

Prevalence of the physical $33.3 \%$ and sexual violence $20.3 \%$ among educated women was almost similar to the violence experienced by the disable women in Nepal (Puri, Mishra, \& Hawkes, 2015) and intimate partner violence among general and urban population in Kathmandu (Oshrio, Poudyal, Poudel, \&Jimba, 2011). This finding suggests that all Nepalese women are vulnerable and have greater risk of violence. Emotional violence was one of the common forms of violence, and one-third of women had experienced emotional violence in the past 12 months. This study found that about one-fifth of educated women had experienced some forms of sexual abuse in their life. Similarly, findings on physical or sexual violence against women of childbearing age within marriage in Nepal, based on nationally 
representative data set reported $14 \%$ of women experienced sexual violence by their husband (Pandey, 2014). Whereas the similar type of study conducted in rural part of Nepal (Achham, Gulmi, Rupendehi, \& Ilam) showed that about three in five married women experienced any forms of sexual violence in their life (Watts, \&Zimmerman, 2002). The result of the studies on the experience of IPV was mixed for rural/urban, educated/uneducated women. However, all Nepalese women are at the risk of IPV. It may also be due the existing similar cultural, religious norms and values among all Nepalese women.

Moreover, this study concludes that access to wealth (i.e. land ownership or cash from employment) had a protective effect on the experience of all types of violence from their husband compared to those who did not have, similar findings were from some studies (Pandey, 2014; Oduro, Deere, \& Catanzarite, 2015). For example; a study conducted in Nicaragua and Tanzania on women's landownership and relationship with violence against women documented that when women owned land they gained power and were less likely to experience violence (Grabe, Grose, \& Dutt, 2015). Finding of this study also shows that respondents who were involved in civic/ political union, social work/ charitable organizations, economic/micro finance, women's organization, religious organizations, sports/arts/ crafts were less likely to experience all three types of violence than those who were not involved. Probable reasons could be those women were open on the GBV matters, aware of the violence act upon them and tried to establish their basic rights within a husband-wife relationship. Husband's higher level of education was a positive factor for the lower level of IPV. 


\section{Limitations}

This study used self-administered questionnaires which might have limited the lower response rate (about 75\%. Students were purposively selected from one of the Tribhuvan University's female college in Kathmandu for the crosssectional survey and analyzed only the response of 123 married respondents. Therefore, it is not assumed that the findings represent the overall prevalence of violence against higher educated women. Despite these limitations, this study provides initial evidence of intimate partner violence among higher educated Nepalese university students. So, these findings require further investigations. Further research should be continued to identify the national representative evidence of IPV among educated women.

\section{Conclusion}

This study found that intimate partner violence is prevalent among married university female students in Nepal. Emotional violence was the commonly occurring form of violence. However, physical violence was high for the women living in rural residence and with no employment.

Moreover, this study highlights that urban residence; employment and land ownership of the women were important variables for the low level of IPV among women. Similarly, husband's higher level of education and government employment were the positive factors for low prevalence of IPV. This study also finds that similar level of educational and employment status between husband and 
wife associated with the lower level of IPV. Findings of the study revealed that education only is not the factor to prevent IPV in Nepal. The educational programmes (courses) should be designed in a way that the graduates get employment easily hence to improve financial security for women reducing prevalence of IPV.

\section{Competing interests}

The author declares no competing interests.

\section{References}

Adhikari, A., \& Tamang, J. (2010). Sexual coercion of married women in Nepal.BMC Women's Health. 2010; 10:31 https://bmcwomenshealth.biomedcentral.com/articles/10.1 $\underline{186 / 1472-6874-10-31}$

Asia Foundation. (2010). NEPAL preliminary mapping of gender based violence. Saathi, The Asia Foundation Departmnt for International Development, 1-73. Retrieved from http://asiafoundation.org/resources/pdfs/GBVMappingNe pal.pdf

Butchart, A., Garcia-Moreno, C., \&Mikton, C.(2010) Preventing intimate partner and sexual violence against women: taking action and generating evidence. 2010. World Health Organization, Geneva.

Decker, M.R., et al.(2014). Prevalence and health impact of intimate partner violence and non-partner sexual violence among female adolescents aged 15-19 years in vulnerable 
urban environments: a multi-country study. Journal of Adolescent Health.2014. 55(6): S58-S67

Ellsberg, M., Arango, D.J., Morton, M., Gennari, F., Kiplesund, F., Contreras, M., Watt, C. (2015).Prevention of violence against women and girls: what does the evidence say? The Lancet. 2015; 385(9977): 1555-66

Fulu, E., Warner, X., Miedema, S., Jewkes, R., Roselli, T.,\& Lang, J.(2013). Why do some men use violence against women and how can we prevent it? Quantitative findings from the United Nations multi-country study on men and violence in Asia and the Pacific. Bangkok: UNDP, UNFPA, UN Women and UNV. 2013

Garcia-Moreno, C., Jansen H.A., Ellsberg, M., Heise L, \& Watts, C.H. (2006). Prevalence of intimate partner violence: findings from the WHO multi-country study on women's health and domestic violence. The Lancet. 2006; 368(9543): 1260-1269.

García-Moreno, Claudia et al. (2014). The health-systems response to violence against women. The Lancet. Volume 385, Issue 9977,1567 - 1579

Gass, J. D., Stein D. J., Williams D. R.,\&Seedat, S.(2011). Gender differences in risk for intimate partner violence among south African adults.Journal of Interpersonal Violence 2011; 26(14): 2764-2789.

Geffner, R., Igelman, R.S., \&Zellner, J. (Eds).(2003). The effects of intimate partner violence on children. Routledge. 2003. The Haworth Maltreatment \& Trauma Press: New York.

Government of Nepal. (2012). A study on gender-based violence conducted in selected rural districts of Nepal, (November), VI-6. Retrieved from 
http://bmcpublichealth.biomedcentral.com/articles/10.118 6/s12889-015-1610-z

Grabe, S., Grose. G.G., \&Dutt, A.(2015). Women's land ownership and relationship power: a mixed methods approach to understanding structural inequities and violence against women.Psychology of Women Quarterly. 2015; 1-13. doi: 10.1177/0361684314533485

Hawkes, S.(2013). Tracking cases of gender-based violence in Nepal: individual, institutional, legal and policy analyses 2013. [online] UCL, Institute for Global Health. London. https://www.ucl.ac.uk/igh/research/a-z/tracking-casesgender-based-violence-nepal

Institute of Health Metrics and Evaluation (IHME). (2016). Global Burden of Disease 2015 Data Visualization [GBD Compare: Viz Hub].IHME: University of Washington. Washington DC 2016 http://vizhub.healthdata.org/gbdcompare

Jewkes R.(2002). Intimate partner violence: causes and prevention. The Lancet. 2002; 359(9315): 1423-1429

Karki, C.(2011).Suicide: Leading cause of death among women in Nepal. Kathmandu University Medical Journal (KUMJ).2011; 9(35): 157-158

Lamichhene, P., Puri, M., Tamang, J., \&Dulal, B.(2011).

Women's status and violence against young married women in rural Nepal.BMC Women's Health 2011; 11:19 http://bmcwomenshealth.biomedcentral.com/articles/10.1 186/1472-6874-11-19

Ministry of Health.(2011). Nepal demographic health survey 2011. Kathmandu, Nepal: Ministry of Health and Population, New ERA, and ICF International Calverton, Maryland. 2012 
Oduro, A.D, Deere, C.D., \&Catanzarite, Z. B. (2015). Women's wealth and intimate partner violence: insights from Ecuador and Ghana. Feminist Economics 2015; 21(2): 129,

Oshrio, A., Poudyal, A.K., Poudel, K.C.,\&Jimba, M.(2011). Intimate partner violence among general and urban poor populations in Kathmandu, Nepal. Journal of Interpersonal Violence. 2011; 26(10): 2073-2092

Palermo, T., Bleck, J., \& Peterman, A. (2014).Tip of the iceberg: reporting and gender-based violence in developing countries.American Journal of Epidemiology . 2014; 179(5): 602-612.

Pandey, S. (2014). Physical or sexual violence against women of childbearing age within marriage in Nepal: Prevalence, causes, and prevention strategies.International Social Work 2014. 1-18. doi: 10.1177/0020872814537857

Puri, M., Frost, M., Tamang, J., Lamichhane, P.,\& Shah, I.(2012). The prevalence and determinants of sexual violence against young married women by husbands in rural Nepal.BMC Research Notes. 2012; 5:291 http://bmcresnotes.biomedcentral.com/articles/10.1186/17 $\underline{56-0500-5-291}$

Puri, M., Mishra, G., \&Hawkes, S.(2015). Hidden voices: prevalence and risk factors for violence against women with disabilities in Nepal.BMC Public Health 2015; $15: 261$ https://bmcpublichealth.biomedcentral.com/articles/10.11 86/s12889-015-1610-z

Solotaroff, J.,L., \& Pande R.,P.(2014) Violence against women and girls: lessons from South Asia.South Asia Development Forum. Washington, DC: World Bank. 2014 
Speizer I.S.,\& Pearson, E. (2012) Association between early marriage and intimate partner violence in India: A focus on youth from Bihar and Rajasthan.Journal of Interpersonal Violence 2011; 26(10): 1963-1981.

Staggs, S.L.,\&Riger S. (2005).Effects of intimate partner violence on low-income women's health and employment.American Journal of Community Psychology. 2005; 36(1-2): 133-145.

Stöckl, H., March, L., Pallitto, C., \& Garcia-Moreno, C. (2014).Intimate partner violence among adolescents and young women: prevalence and associated factors in nine countries: a cross-sectional study.BMC Public Health. 2014; 14:751 http://www.biomedcentral.com/1471-2458/14/751

Tuladhar, S., Khanal, K.,R., Ghimire, P.,K. \&, Onta, K.(2013). Women's empowerment and spousal violence in relation to health outcomes in Nepal: further analysis of the 2011 Nepal Demographic and Health Survey. Calverton, Maryland, USA: Nepal Ministry of Health and Population, New ERA, and ICF International Calverton, Maryland. 2013

Watts, C., \&Zimmerman, C. (2002). Violence against women: global scope and magnitude. The Lancet2002; 359(9313): 1232-1237

World Health Organization (2002). World report on violence and health. WHO, Geneva. 2002.

World Health Organization (2005). WHO multi-country study on women's health and domestic violence against women 2005. World Health Organization. Geneva. http://www.who.int/gender/violence/who multicountry st udy/summary report/summary report/en 
World Health Organization. (2012). Understanding and addressing violence against women. 2012. World Health

Organization.

www.who.int/iris/bitstream/10665/77432/1/WHO_RHR

12.36 eng.pd

The author is affiliated to Padmakanya Multiple Campus, Tribhuvan University, Kathmandu, Nepal. 